\title{
Approaches To Learning And Age In Predicting College Students' Academic Achievement
}

\author{
Baris Cetin, Canakkale Onsekiz Mart University, Turkey
}

\begin{abstract}
The aim of this study is to determine whether the approaches to learning and age are significantly correlated to grade point average (GPA) in early childhood education students. In addition, another purpose of this study is to determine whether approaches to learning and age predicted students' GPAs in the Early Childhood Education Department. The sampling of the study consists of 166 students in total (158 female and 8 male; 86 junior and 80 senior) who studied at Georgia Southern University in the United States of America College of Education, Teaching and Learning Department's Early Childhood Education program. The research model is a prediction study. The data in this study was collected using the Revised Two-Factor Study Process Questionnaire (R-SPQ-2F) and a personal information form. The findings were as follow: there was a positive relationship between students' GPAs and the deep approach. There was a negative relationship between GPAs and the surface approach. There was no significant relationship between GPAs and approaches to the total score of learning. While there were no significant relationships between students' ages and deep motivation and surface motivation strategies, an association was found between age and approaches to total scores of learning total. The approaches to total score of learning were not significant predictors of GPA.
\end{abstract}

Keywords: Early Child Education; Approaches to Learning; Age; Grade Point Average

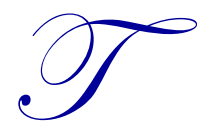

here are many factors affecting students' learning. Some of these factors are motivation (Pintrich and Schunk, 2002), intrinsic motivation (Deci and Ryan, 1985) students' learning Strategies, Study Skills (Winne, 2013); self-regulation learning (Zimmerman and Kitsantas, 2005; Winne, 2011), metacognitive skills (Schraw, Crippen, Hartley, 2006), epistemic beliefs (Winne and Nesbit, 2010), approaches to learning and age this article, two of these factors are discussed: approaches to learning and age.

\section{Approaches to Learning}

Marton and Sa"ljo“ (1976) investigated deep and surface approaches to learning (Marton and Sa“1jo“, 1976). The main purpose of good education is to direct students to use a deep approach and to prevent the use of the surface approach (Biggs, 1999a). In an ideal system, it is expected that all students deal with the problem at hand in the most appropriate way by engaging in learning activities at the highest level to solve the problem at hand. Students who use the surface approach would use lower level verbs. The presence of the surface approach indicates that something is dysfunctional in our methods of education or assessment (Biggs, Kember, \& Leung, 2001).

In a study by Biggs (1999b), it was found that students used a deep approach to learning main topics regardless of education methods (Biggs, 1999b). The deep approach, which can be defined with a combination of intention and processes, emphasizes understanding the learning processes and is a clearly different concept from organizing effort and concentration-related studying strategies (Entwisle \& McCune, 2004). The majority of previous studies on student learning considered high quality learning in terms of deep approach, which results in conceptual understanding (Entwisle, 2005).

The deep approach is directed by the need to complete a task in an appropriate and meaningful way, which leads to using the most appropriate cognitive functions for working on a task. The use of deep approach creates positive feelings such as interest, feeling important, challenge, and even exhilaration. On the other hand, the surface 
approach is related to the intention of finishing a task without putting much effort in it and seeming to fulfill requirements, leading to the use of lower cognitive activities even if the task requires higher level activities. The surface approach is not only seen in learning but also in many other areas such as teaching or doing business. The surface approach is also defined as "cutting corners" or "sweeping under the carpet," which are two commonly used idioms. (Biggs, 1999a).

Students who use the deep approach would not have the intention of finding shortcuts for dealing with a task. Instead, they would try to find meaning in the taught material and learn in the most wanted way (Biggs, 2012a). The deep approach occurs in accordance with the students' intention. In the surface approach, students try to guess what their teachers would expect from them in examinations and search for expected questions within the taught material. Students who depend on the deep approach handle a task with the intention of learning the material for themselves, which in turn would enable them to comprehend the meaning of the taught material (Entwisle, 2009).

Students who use the surface approach fail to grasp the real purpose of a task and try to finish the task by investing the minimum amount of time and effort in order to meet the learning requirements. As a result, low level cognitive activities are used even if the task requires higher level activities and rote learning content without understanding is very common. However, the rote learning itself does not necessarily mean that the surface approach is used and is an appropriate method when verbatim recall is required. The inappropriate use of rote learning indicates a surface approach, such as memorizing answers of a previous examination (Biggs, 2001). When the surface approach is adopted, the learners focus on the surface characteristics of a situation, on the wording of a text, of the proposed argument, on figures in a problem, and on the formulas for solving a problem (Bowden \& Marton, 1998).

As mentioned before, the deep approach depends on intrinsic interest to complete the task in an appropriate and meaningful way. With this regard, the underlying meaning and the main ideas, themes, and principles become important instead of the details and unsupported specifics. A deep approach, which uses analogy, metaphors, and conceptual structures, requires a strong background and relevant prior knowledge. Strategies used for creating meaning differ from task to task, and the readiness for the use of such strategies is related to the quality of teaching. The main characteristic of deep approach involves students' engagement in a task by using the most appropriate learning processes for completing the task satisfactorily (Biggs, 2001). In a deep approach, students focus on the object of learning and on the phenomenon in the taught material (Bowden \& Marton, 1998).

While the surface approach requires routine memorization, the deep approach involves making connections with previous knowledge and reasoning. The essence of the surface approach is that it uses rote learning, which derives from the intention to reproduce of the material presented by the teacher, in a routine way and without thinking (Entwisle \& Smith, 2002). Neither the surface nor the deep approaches to teaching are inherent to the specific teacher. Thought processes may be reactions to the teaching environment. Using the deep approach and avoiding the surface approach forms the basis of high quality teaching; meanwhile, many traditional methods have the opposite effect (Biggs, 1999a).

Academic students adopt a deep approach to learning regardless of the teaching methods used; whereas nonacademic students adopt a deep approach only if the most appropriate education conditions are present. A deep approach defines the required activities for reaching the appropriate result regarding the task at hand. A surface approach takes low cognitive level activities as reference and cannot produce the appropriate results (Biggs, 1999b). What makes the two approaches different from one another is that surface approaches focus on "the sign" but deep approaches focus on "the signified" (must add citation including page number for direct quote here). Deep approaches are associated with comprehending the author's message, while surface approaches involve misunderstanding or missing the message. Students who use the deep approach focus on meaning while reading a text, whereas those who use the surface approach focus on words (Marton \& Booth, 2009).

\section{Predicting Academic Achievement by Approaches to Learning}

Diseth (2003) found that academic achievement is predicted by approaches to learning. Diseth, Pallesen, Brunborg, and Larsen (2010) reported that surface and deep approaches to learning had mediating effects between test performance and course experience. They indicated that the approach to learning is an independent predictor of test 
performance. Salamonson et al. (2013) found that surface and deep approaches to learning are important predictors of academic performance. Choy, O'Grady, and Rotgans (2012) determined that students' approaches to learning are a weak predictor of academic achievement. Duff, Boyle, Dunleavy, and Ferguson (2003) indicated that the deep, surface, and strategic approaches are weak predictors of academic achievement. Lizzio, Wilson, and Simons (2002) determined that the surface approach to learning is a better predictor of GPAs than deep approaches to learning among college students. Burton and Sztaroszta (2007) found that deep approaches to learning cannot positively predict academic achievement.

\section{PURPOSE}

The aim of this study was to determine whether the approaches to learning and age are significantly correlated to GPAs in early childhood students' education. In addition, another aim of the study was to determine if approaches to learning and age significantly predict GPAs in early childhood education students.

\section{METHOD}

The purpose of a prediction study is to determine variables that would positively predict an outcome or criterion variable (Creswell, 2008). Prediction studies are conducted in order to determine the prediction of the reliability of measures, to assist in various types of choice, and to carry out decisions made pertaining to individuals (Gay, Mills, \& Airasian, 2009). A prediction study is used as a different design in correlation research and examined the correlations between variables (Lodico, Spaulding, \& Voegtle, 2010). In prediction studies, correlation coefficients show how a variable is predicted by another variable (McMillan, 2008). The model of the present study is a prediction study because it aims to test the predictive relationship of approaches to learning and age to early child education students' GPAs.

\section{Participants}

The sampling of the study consists of 166 students in total (158 female and 8 male) who studied at the Georgia Southern University (GSU) in the United State of America, College of Education, Teaching and Learning Department, Early Child Education program.

\section{Study Process Questionnaire}

The Study Process Questionnaire was developed by Biggs (1987). The questionnaire contains 43 items and three subfactors, namely; deep, surface, and achievement. The Revised Two-Factor Study Process Questionnaire (R-SPQ2F), which was revised by Biggs et al. (2001), was used in this study. The revised two-factor questionnaire was developed in order to enable teachers to evaluate the learning environment in their classrooms and contains 20 items. The two subfactors of the questionnaire are the deep approach, which has a Cronbach's alpha coefficient of 0.73, and the surface approach, which has a Cronbach's alpha coefficient of 0.64. Each subfactor includes 10 items and all the items in the questionnaire are positive. The maximum score that can be obtained from the questionnaire is 100 , whereas the minimum score is 20 (Biggs et al., 2001).

\section{Personal Information Form}

Data on GPA was collected according to the students' self-report. The form consisted of questions about students' GPA, gender, and age. The GPA corresponded to the general average of all course grades in the fourth and fifth semesters among junior students and sixth and seventh semesters among senior students studying at GSU's COE.

\section{Procedures}

Research data were collected during the spring semester of GSU's COE in 2014. The Study Process Questionnaire and the personal information form were administered to the 86 junior and 68 senior students. The instrument was administered to 12 students who were studying in the second semester of the fourth year via the Qualtrics (online research surveys) used by the Georgia Southern University. 
Multiple regression is used for determining the correlations between variables and a criterion and is the best technique for combining two or more predictor variables (Fraenkel \& Wallen, 2006). Therefore, multiple regression analysis was used in the study. The correlations of the scores obtained from the Study Process Questionnaire and students' age to GPAs were tested using the Pearson Product-Moment Correlation. In order to determine whether the scores obtained from the Study Process Questionnaire and students' age, together predict GPAs, the multiple regression analysis was used.

\section{RESULTS}

In this section, the results of the Pearson Product-Moment Correlation, which was carried out in order to determine whether there are significant correlations between early child education students' approaches to learning, age, and GPAs, are provided. In addition, results of the multiple regression analysis, which was conducted to determine whether early child education students' approaches to learning and age together predict GPAs, are given.

According to Table 1, students obtained the highest mean in the deep approach subfactor and the lowest mean in the surface approach subfactor.

Table 1. Means and standard deviations of approaches to learning total scores, sub factors, and age

\begin{tabular}{lcc}
\multicolumn{2}{c}{ Table 1. Means and standard deviations of approaches to learning total scores, sub factors, and age } \\
\hline GPA & $\boldsymbol{M}$ & $\boldsymbol{S D}$ \\
Deep approach & 3.3315 & .41301 \\
Surface approach & 3.0602 & .64853 \\
Approaches to learning total score & 2.6145 & .62921 \\
Age & 2.8795 & .47731 \\
N & 21.8855 & 3.46132 \\
\hline
\end{tabular}

The Relationship of Approaches to Learning and Age to GPAs

Table 2. Correlations of GPA to Approaches to Learning and Age

\begin{tabular}{|c|c|c|c|c|c|}
\hline & GPA & Age & $\begin{array}{c}\text { Deep } \\
\text { approach }\end{array}$ & $\begin{array}{c}\text { Surface } \\
\text { approach }\end{array}$ & $\begin{array}{c}\text { Approaches } \\
\text { to learning } \\
\text { total score }\end{array}$ \\
\hline GPA & 1 & -.143 & .029 & -.021 & .057 \\
\hline Age & -.143 & 1 & $.173^{*}$ & $-.196^{*}$ & .006 \\
\hline Deep Approach & .029 & $.173^{*}$ & 1 & -.002 & $.474^{* *}$ \\
\hline Surface Approach & -.021 & $-.196^{*}$ & -.002 & 1 & $.551^{* *}$ \\
\hline Approaches to learning total score & .057 & .006 & $.474^{* *}$ & $.551^{* *}$ & 1 \\
\hline
\end{tabular}

* Correlation is significant at the 0.05 level (2-tailed).

** Correlation is significant at the 0.01 level (2-tailed).

As shown in Table 2, there was no correlation between students' GPA and the deep approach and the surface approach. There was negatif relationship between students' GPA and approaches to learning total score. There was negatif relationship between students' age and the surface approaches. There was relationship between student's age and deep approaches. There was correlation between students' approaches learning total scores deep approach and surface approaches. There wasn't a significant relationship between students' age and GPA. 


\section{Prediction of GPA by Approaches to Learning and Age}

Table 3. Results of the multiple regression analysis regarding the prediction of GPAs by approaches to learning total score and age

\begin{tabular}{lccccc}
\hline & B & Standard Error B & B & \multicolumn{1}{c}{$\boldsymbol{t}$} \\
\hline Deep approach & -.002 & .060 & -.003 & -.036 & .971 \\
Surface approach & -.082 & .066 & -.125 & -1.231 & .220 \\
Approaches to learning total score & .111 & .098 & .129 & 1.139 & .256 \\
Age & -.020 & .010 & -168 & -2.086 & .039 \\
\hline
\end{tabular}

$R=.184, R^{2}=.034$

$\mathrm{F}_{(4-161)}=1.411, p>.233$

According to Table 3, students' approaches to total scores of learning and age together do not predict their GPAs at a significant level $(p>.233)$. Students' approaches to learning total scores and age together explain .034 of the variance in GPAs. When I examined the $t$-test results pertaining to the significance of the regression coefficients, I observed that only age was a significant predictor of GPAs. It was determined that the deep approach, the surface approach, and approaches to learning total scores do not predict students' GPAs at a significant level.

\section{DISCUSSION}

This study, which aimed to determine whether the approaches to learning and age are significantly correlated to GPAs in early child education students and to determine if approaches to learning and age significantly predict GPAs in early childhood education students, yielded the following results.

Between students' GPA and the deep approach, the surface approach was no correlation found. Results of previous studies support this finding, as follow. In a meta-analytic study by Watkins (2001), it was determined that the magnitude of the correlation between approaches to learning and academic achievement ranged from -.11 to .16 in 27,078 participants from 15 countries. Heikkila and Lonka (2006) found a low positive relationship between academic average and the deep approach to learning. Diseth (2002) determined a negative correlation between the surface approach and academic achievement and found that deep strategy affected academic achievement. Diseth (2007) found a positive correlation between examination scores and the deep approach. Diseth (2003) determined a significant negative relationship between achievement and the surface approach and a positive relationship between achievement and the deep approach. Matthews, Lietz, and Gurah (2007) found a moderate association between deep learning and achievement strategy and a negative association between deep learning and surface strategy. Mohd Redza, Ismail, Sarif, and Ismail (2013) found a positive relationship between deep approaches and academic performance and a negative relationship between the surface approach and examination results. Rosenthal (2012) reported that the deep and surface learning approaches were negatively related to achievement. Zeegers (1999) determined a strong positive correlation (.41) between the deep approach to learning and academic achievement and also determined that the deep and strategic learning approach was positively associated with academic achievement and that the surface learning approach was negatively related to academic achievement. Ekinci (2009) reported that there was a significant and positive correlation between students' level of achievement and deep and strategic learning approaches and that there was a significant and negative relationship between the surface learning approach and achievement.

Under the light of these findings, it can be suggested that the results of my study are in parallel with previous research. The findings of previous studies which investigated the relationship of deep and surface approaches to GPA support my findings. The deep approach scores increased and the surface approach scores decreased as the students' GPAs increased.

In this study, I did not find a significant relationship between students' GPA and approaches to learning total score. This finding shows that students' approaches to learning total scores are not related to GPA. This finding can be explained by the fact that the students' GPAs were packed in a specific interval. Another explanation is that there are numerous different factors affecting the GPA and therefore I could not determine a significant relationship between GPA and the approaches to learning total score. In my study there was negative relationship between students' age and surface approaches. In my study there was a significant relationship between students' age and the 
deep approaches. Students' ages were correlated to approaches to total score of learning. Age is thought to have a significant effect on the levels of learning approaches.

Students' approaches to total scores of learning and age together did not predict their GPAs at a significant level. In the literature, approaches to learning were reported to predict GPAs at a significant level; however, our finding is inconsistent with this result. It is thought that numerous factors affect the prediction of students' GPAs. These factors include intelligence, attitudes, studying habits, anxiety, thinking skills, self-efficacy, and motivation. These factors are considered to be important variables in the prediction of GPA. In addition, the fact that the students' GPAs were packed in a specific interval is thought to be the cause of not being able to predict GPA by approaches to learning and age together.

\section{Limitations}

The participants of this study only consist of the junior and senior students from, GSU, College of Education and few male students. The data of the study was gathered through the use of, the questionnaire of "The Study Process Questionnaire" and GPAs of students' oral expressions from GSU College of Education.

\section{Recommendations for Further Research}

Under the light of our results, the following suggestions can be made:

- It can be investigated whether approaches to learning and age together predict academic achievement in junior and senior students who study at other colleges of education, teaching, and learning, early childhood education programs in different states of America.

- It can be investigated whether Georgia Southern University COE's, junior and senior students' approaches to learning and age are related to GPA that will be obtained through the official records at course level.

- The students' approach learning scores from GSU and College of Education in the State of Georgia, which is one of the several states in the USA and students' ages can be used to investigate if they all predict students' academic achievements in their courses.

- The interview method, which is one of the qualitative research methods, can be used to find out if the learning approaches of the College of Education students studying at different states of the USA and GSU can be used to predict if the courses students take at undergraduate level predict their academic achievements.

\section{AUTHOR BIOGRAPHY}

Baris Cetin is an assistant professor in Elementary Education at Canakkale 18 March University in Turkey. He gained his Bachelors Degree in Elementary Education from Canakkale 18 Mart University, and also his masters in 2002. He received his Ph.D. in Elementary Education in 2007 from Marmara University. Dr. Cetin was a visiting Assistant Professor at Georgia Southern University in the United States of America from 2013 to 2014 and a did his post doctora fellowship in the Simon Fraser University in Canada from 2015 to 2016. His research interests include self-efficacy, academic motivation, and metacognitive skill, self-regulated learning, and teacher education, approaches to learning, and preservice teacher education.

\section{REFERENCES}

Biggs, J. B. (1987). The Study Process Questionnaire SPQ: Manual. Hawthorn, Australia: Australian Council for Educational Research. Retrieved from http://files.eric.ed.gov/fulltext/ED308200.pdf.

Biggs, J. B. (1999a). Teaching for quality learning at university. Buckingham, UK: Open University Press.

Biggs, J. (1999b). What the student does: Teaching for enhanced learning. Higher Education Research \& Development, 31(1), 39-55.

Biggs, J., Kember, D., \& Leung, D. Y. P. (2001). The revised two-factor Study Process Questionnaire: R-SPQ-2F. British Journal of Educational Psychology, 71(1), 133-149.

Biggs, J. (2001). Enhancing learning: A matter of style or approach? In R. J. Sternberg \& L. F. Zhang (Eds.), Perspectives on 
thinking, learning, and cognitive styles (pp. 73-102). Mahwah, NJ: Lawrence Erlbaum Associates.

Biggs, J. (2012a). Enhancing learning through constructive alignment. In Kirby, J.R. \& Lawson, M.J. (Eds.), Enhancing the quality of learning: Dispositions, instruction, and learning processes (pp.117-136). Cambridge University Press: Cambridge, New York, Melbourne, Madrid, Cape Town, Singapore, Sao Paulo, Delhi, Mexico City.

Bowden, J., \& Marton, F. (1998). The university of learning beyond quality and competence. London, UK: Routledge Falmer, Taylor \& Francis Group.

Burton, L. B., \& Sztaroszta, J. (2007). The relationship among conceptions of knowledge, approaches to learning, personality, and academic success. Toowoomba, Australia: Australian Psychological Society.

Choy, J.L.F., O'Grady, G., \& Rotgans, J.I. (2012). Is the Study Process Questionnaire (SPQ) a good predictor of academic achievement? Examining the mediating role of achievement-related classroom behaviours. Instr Sci. 40, 159-172 Doi 10.1007/s11251-011-9171-8.

Creswell, J.W. (2008). Educational research Planning, conducting, and evaluating quantitative and qualitative research. Pearson Merrill Prentice Hall, New Jersey.

Deci, E. L., \& Ryan, R. M. (1985). Intrinsic motivation and self-determination in human behavior. Plenum Press: New York and London.

Diseth, A. (2002). The Relationship between Intelligence, Approaches to Learning and Academic Achievement. Scandinavian Journal of Educational Research, Vol. 46, No. 2, 219-230. DOI: 10.1080/00313830220142218.

Diseth A. (2003). Personality and approaches to learning as predictors of academic achievement. European Journal of Personality Eur. J. Pers., 17, 143-155. DOI: 10.1002/per.469

Diseth, A. (2007). Students' evaluation of teaching approaches to learning, and academic achievement. Scandinavian Journal of Educational Research, 51 (2), 185-204. DOI: 10.1080/00313830701191654.

Diseth, A., Pallesen, S., \& Brunborg, G.S., Larsen, S. (2010). Academic achievement among first semester undergraduate psychology students: The role of course experience, effort, motives and learning strategies. High Educ. 59, 335-352. DOI 10.1007/s10734-009-9251-8

Duff, A., Boyle, E., Dunleavy, K. Ferguson, J. (2003). The relationship between personality, approach to learning and academic performance. Personality and Individual Differences, 36,1907-1920. doi:10.1016/j.paid.2003.08.020

Ekinci, N. (2009). Learning Approaches of University Students. Education and Science. 2009, Vol. 34, No 151.

Entwistle, N., \& McCune V. (2004). The Conceptual Bases of Study Strategy Inventories. Educational Psychology Review, 16, 4, 325-345.

Entwistle, N., \& Smith, C. (2002). Personal understanding and target understanding: Mapping influences on the outcomes of learning. British Journal of Educational Psychology, 72, 321-342.

Entwistle, N. (2005). Learning outcomes and ways of thinking across contrasting disciplines and settings in higher education. The Curriculum Journal. Vol. 16, No. 1, pp. 67 - 82. DOI: 10.1080/0958517042000336818.

Entwistle, N. (2009). Universities into the $21^{\text {st }}$ century, teaching for understanding at University: Deep approaches and distinctive ways of thinking. Palgrave macmillan: New York.

Gay, L.R., Mills, G.E., Airasian, P., (2009). Educational Research competencies for analysis and applications. Pearson Education: New Jersey.

Fraenkel, J.R., Wallen, N.E. (2006). How to design and evaluate research in education. Mc Graw Hill Higher Education. New York, NY.

Heikkilä, A., \& Lonka, K. (2006). Studying in higher education: students' approaches to learning, self-regulation, and cognitive strategies. Studies in Higher Education, 31,1,99-117. DOI: 10.1080/03075070500392433

Lodico, M.G., Spaulding, D.T., Voegtle, K.H. (2010). Methods in educational research from theory to practice. Jossey-Bass A Wiley Imprint: San Francisco

Lizzio, A. , Wilson, K., \& Simons, R. (2002). University students' perceptions of the learning environment and academic outcomes: Implications for theory and practice. Studies in Higher Education, 27, 27-52. DOI: 10.1080/0307507012009935 9

Matthews, B., Lietz, P., \& Gurah, G. (2007). Values and learning approaches of students at an international university. Social Psychology of Education, 10, 247-275. DOI: 10.1007/s11218-007-9019-x

Mohd Redza, Z.E., Ismail, S., Sarif, S.M., Ismail, Y. (2013). Do approaches to learning affect academic performance of business ethics students. Journal of Technical Education and Training, 5 (1)|, 1-16 Retrieved from http://penerbit.uthm.edu.my/ojs/index.php/JTET/article/view/691/448

McMillan, J. (2008). Educational Research Fundamentals for the consumer. Pearson Education: Boston.

Marton, F., \& Sa"ljo“, R. (1976). On qualitative differences in learning. I-Outcome and process. British Journal of Educational Psychology, 46, 4-11. DOI: 10.1111/j.2044-8279.1976.tb02980.x

Marton, F. \& Booth, S. (2009). Learning and Awareness. Routledge Taylor\& Francis Group: New York and London.

Pintrich, P.R.; Schunk, D.H. (2002). Motivation in education theory, research, and applications. Upper Saddle River: New Jersey, Columbus, Ohio.

Rosenthal J.L. (2012). Motives and methods: Motivation, learning approaches, and academic achievement of students during first year transition to medical school (Unpublished doctoral dissertation). University of Southern California, Los Angeles. 
Salamonson, Y., Roslyn Weaver, R., Chang, S., Koch, J., Bhathal, R., Khoo, C., \& Wilson, I.(2013). Learning approaches as predictors of academic performance in first year health and science students. Nurse Education Today, 33, 729-733. http://dx.doi.org/10.1016/j.nedt.2013.01.013

Schraw, G., Crippen, K.J., Hartley, K. (2006). Promoting self-regulation in science education: Metacognition as part of a broader perspective on learning. Research in Science Education, 36, 111-139. DOI: 10.1007/s11165-005-3917-8

Watkins, D. (2001). Correlates of approaches to learning: A cross-cultural meta-Analysis. In Sternberg R.J.\& Zhang, L.F. (Eds.), Perspectives on thinking, learning, and cognitive styles (pp.165-195). Lawrence Erlbaum Associates: Mahwah, NJ.

Winne, P. H. (2011). A cognitive and metacognitive analysis of self- regulated learning. In B. J. Zimmerman and D. H. Schunk (Eds.), Handbook of self-regulation of learning and performance (pp. 15-32). New York: Routledge.

Winne, P. H., \& Nesbit, J. C. (2010). The Psychology of Academic Achievement. Annual Review of Psychology, 61, 653-678.

Winne, P. H. (2013). Learning strategies, study skills and self-regulated learning in postsecondary education. In M. B. Paulsen (Ed.), Higher education: Handbook of theory and research. Volume 28 (pp. 377-403). Dordrecht: Springer.

Zimmerman, B.J; Kitsantas, A. (2005). A. The hidden dimension of personal competence: Self-regulated learning and Practice. In A.J. Elliot, \& C.S. Dweck (Eds.), Handbook of Competence and Motivation (pp.509-526). The Guilford Press: New York London.

Zeegers, P. (1999). Student learning in science: A longitudinal study using the Biggs SPQ. Paper presented at HERDSA annual international conference. Retrieved fromhttps://www.herdsa.org.au/wpcontent/uploads/conference/1999/pdf/Zeegers.PDF 